\title{
Decision Support System for Selection of Outstanding Students at the Faculty of Mathematics in Natural Sciences at the University of Yogyakarta with AHP and TOPSIS Methods
}

\author{
Aan Yulianto
}

Program Studi Matematika, Jurusan Pendidikan Matematika, Fakultas MIPA, Universitas Yogyakarta

\begin{tabular}{|c|c|}
\hline Article Info & ABSTRACT \\
\hline $\begin{array}{l}\text { Article history: } \\
\text { Received: } 08 / 05 / 2021 \\
\text { Revised: } 11 / 06 / 2021 \\
\text { Accepted: } 04 / 07 / 2021 \\
\text { Available online } 30 / 09 / 2021 \\
\end{array}$ & $\begin{array}{l}\text { Yogyakarta State University (UNY) annually holds the selection of } \\
\text { outstanding students for the Bachelor (S1) program, namely students } \\
\text { who have achieved high achievements, both curricular, co-curricular, } \\
\text { and extra-curricular according to the specified criteria. To assist in } \\
\text { determining the winners of outstanding students, a Decision Support } \\
\text { System (SPK) is needed that is able to provide alternative solutions. }\end{array}$ \\
\hline $\begin{array}{l}\text { Keywords: } \\
\text { Decision Support System, } \\
\text { AHP, } \\
\text { TOPSIS, }\end{array}$ & $\begin{array}{l}\text { The method used in the SPK for the Selection of Outstanding Students } \\
\text { uses the Analytical Hierarchy Process (AHP) for weighting the criteria } \\
\text { and the Technique For Order Preference by Similarity to Ideal Solution } \\
\text { (TOPSIS) to find the winning solution. The design of the SPK for the } \\
\text { Selection of Outstanding Students uses the Waterfall model. The output } \\
\text { of the system is presented in the form of calculation results of AHP and } \\
\text { TOPSIS which can be considered further by decision makers. SPK is } \\
\text { built based on a website designed using Sublime software (text editor), } \\
\text { Database Management System (DBMS) MySQL Xampp } 7 \text { and PHP } \\
\text { programming language. The DSS is tested on users and experts. Based } \\
\text { on the test, the results show that Correctness is included in very good } \\
\text { criteria, Reliability is included in very good criteria, Integrity is } \\
\text { included in very good criteria, Usability is included in good criteria, } \\
\text { meaning that SPK can meet user needs, such as assisting the } \\
\text { registration process, judging and processing data for election } \\
\text { participants the most oustanding student. SPK can display information } \\
\text { according to user input correctly. Instructions for using DSS help users. } \\
\text { SPK is safe from unauthorized parties. The appearance of the SPK is } \\
\text { attractive and easy to use. }\end{array}$ \\
\hline
\end{tabular}

This is an open access article under the CC BY-NC license.

\section{Corresponding Author:}

Aan Yulianto,

Program Studi Matematika,

Jurusan Pendidikan Matematika,

Fakultas MIPA, Universitas Yogyakarta

E-mail: yulianto@gmail.com

\section{Introduction}

College is a place for students to study according to their respective interests and talents. Among universities, there is an event where students will be selected and entitled to become outstanding students and are given awards every year. Outstanding students must meet several criteria, the assessment criteria are academic and non-academic. Academic criteria include the Grade Point Average while non-academic criteria such as activeness in organizations, committees, championship achievements or other extracurricular activities. Personality and communication skills are also considered in the selection of these outstanding students. 
Yogyakarta State University (UNY) is one of the universities in Yogyakarta which annually holds the Selection of Outstanding Students (MAPRES). The system or path for the presidential election at UNY is as follows: 1). Students volunteer to participate in the selection of outstanding students in each of their respective majors. 2). Continued selection at the Department level. 3). Winners from each Department will participate in the selection selection at the Faculty level. 4). Winners from each Faculty will follow the selection selection at the University level. 5). From the university selection stage, one winner will be an outstanding student to represent UNY

Prospective outstanding students who volunteer each year are not small in number and submissions are made by collecting files at the Head of the Student Affairs Subdivision. Judging is carried out by a committee formed by the Head of Student Affairs and data processing has so far been carried out with the help of Microsoft Office Excel. Data processing is carried out according to the calculation reference in the Guidebook for Selection of Outstanding Students of the Undergraduate Program. To facilitate the selection of outstanding students, it is necessary to create a system that is able to provide the results of winners of outstanding students and facilitate the process of selecting outstanding students in this case registration, judging, and data processing. For that, we need a Decision Support System (SPK) that can take into account all the criteria that support student selection decisions quickly,

The criteria for selecting outstanding students refer to the individual performance of students who meet several elements, (UNY, 2013: 6), namely: academic achievement (Cumulative Achievement Index), scientific writing, superior achievement/ability, English/Foreign language skills, and personality.

There are many methods in solving problems in decision making, so the method chosen for selecting outstanding students is

Analytical Hierarchy Process (AHP) and Technique For Order Preference by Similarity to Ideal Solution (TOPSIS). AHP is a supporting model whose main equipment is a functional hierarchy whose main input is human perception (Manurung, 2010: 2).

While the TOPSIS method is a decision support method based on the concept of the best alternative not only having the shortest distance from a positive ideal solution but also having the longest distance from a negative ideal solution which in this case provides recommendations for student achievement decisions as expected (Manurung, 2010). : 2).

The results of the decision making from this SPK can make it easier to determine the winners of outstanding students at the Faculty of Mathematics and Natural Sciences (FMIPA) Yogyakarta State University (UNY). However, the results of this decision making are not absolute because of the decision-making system.

\section{Method}

\subsection{System Feasibility Analysis}

Yogyakarta State University annually holds a selection of outstanding students. In accordance with the rules of the guidebook for selecting outstanding students for undergraduate programs, outstanding students are students who have achieved high achievements, both curricular, cocurricular, and extra-curricular according to the specified criteria.

Outstanding students must be able to meet criteria such as the Grade Point Average (GPA), scientific writing, superior achievement/ability, English/Foreign language and personality. The assessment of outstanding students is carried out by several judges appointed by the Head of Student Affairs. The jury assesses scientific papers, English/Foreign languages, personality and verification of superior achievements/ability by using a predetermined assessment weight.

The SPK for the Selection of Outstanding Students is built on a Web basis so that it requires assistance tools such as:

a. Windows 7 operating system.

b. Software Sublime 2.0 as a text editor.

c. Database Management System (DBMS) MySQL Xampp 7.

d. Mozilla Firefox web browser. 


\subsection{Process Design}

The process design is described in the form of Data Flow Diagrams (DFD) starting from the highest level, namely level 0 (Context Diagram) which describes the system as a whole which is then lowered to lower levels. The following is a DFD that describes the flow of data in the Decision Support System for the Selection of Outstanding Students of FMIPA UNY.

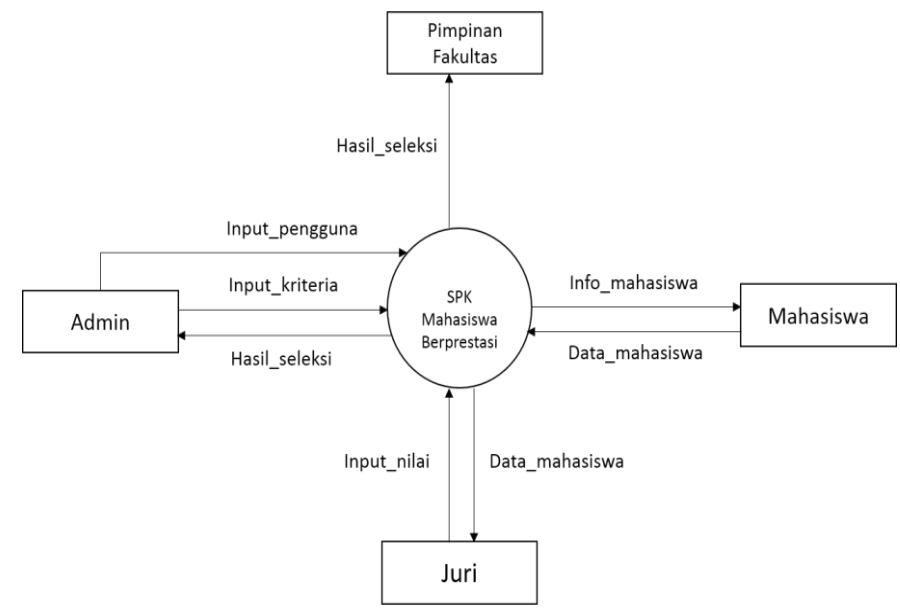

Figure 1. Context Diagram

The context diagram in Figure 1 illustrates that the Decision Support System for the Selection of Outstanding Students of FMIPA UNY interacts with 4 external entities.

Furthermore, the TOPSIS calculation process is described in detail in DFD level 3 TOPSIS Calculation Process in Figure 16. At DFD level 3 this is a selection process with calculations using the TOPSIS method. There are 7 stages of the process, namely the initial data process, conversion, weight normalization, positive negative ideal solution, separation measure and the final result process (ranking). 


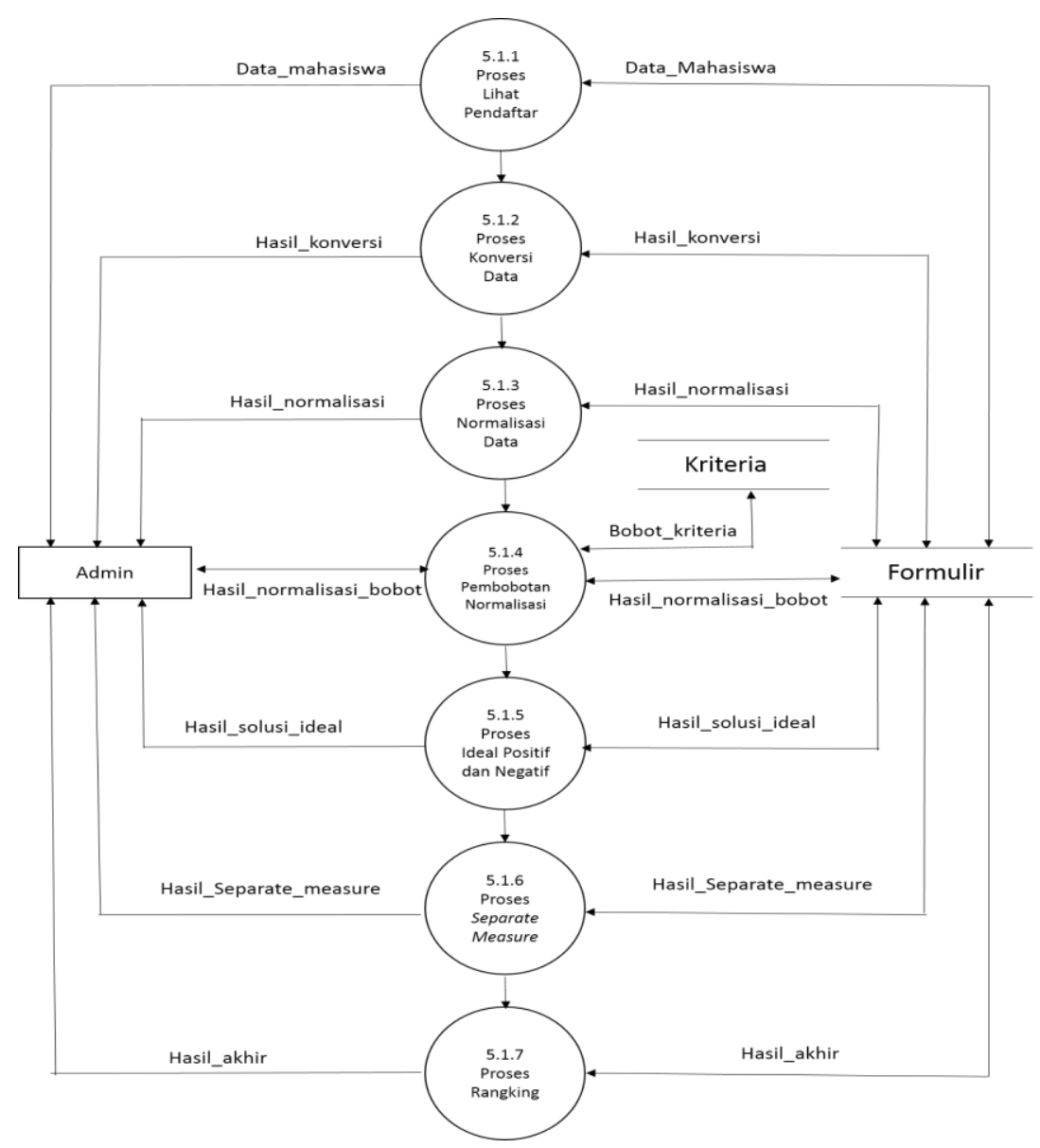

Figure 2.DFD Level 3 TOPSIS Calculation

In Figure 2, the initial data process is the initial process of the TOPSIS method, this process will display all participants in the selection of outstanding students who are equipped with scores on each of the predetermined criteria.

The Conversion Process is the conversion process from the registrant's data to the conversion of a predetermined value. Then the Normalization Weighting Process is the process of multiplying the product with the converted data multiplied by the criteria weight data that has been obtained from the AHP calculation. The positive and negative ideal solution process is the process of finding the highest and lowest scores from all participants according to their respective criteria. The Separation Measure process was continued to find the dmax and dmin of each participant. The Final Result Process (ranking) is a calculation of the proximity values of dmax and dmin with positive or negative ideal solutions.

\section{Results and Discussion}

\subsection{System Implementation}

The system is made web-based using the PHP programming language and MySQL database. The interface is designed using a responsive design, namely the appearance of the website will follow the monitor screen used. The display will be more optimal if you use a monitor screen with a resolution of $1366 \times 768$ pixels. Based on the design above, the implementation of the information system interface is as follows:

\section{a. Login Menu Interface}


The interface that first appears when the program is run is the login menu display which is presented in the following figure. The program code (login.php) as a whole from the interface can be found in the appendix. The user or system user must first log in to find out the access rights (roles) in the student decision support system with this interpretation, if the user logs in as an Admin it will be directed to the Admin Home, the Jury will be directed to the Jury Homepage and the Students will be directed to the Student Homepage. The process of checking the access rights of each logged in user is (authentication.php).

Website Pemilihan Mahasiswa Berprestasi UNY

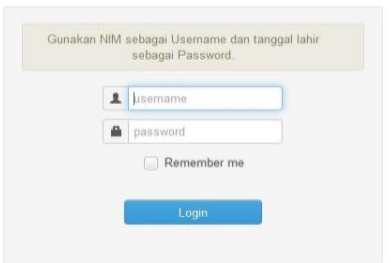

Figure 3. Login Menu Interface

b. Admin Menu Interface

The implementation of the Admin menu interface is Home, Users, MAPRES Registrants, AHP Data Processing (consisting of Criteria Input, Number of Columns, Criteria Normalization, Criteria Weighting), TOPSIS Data Processing (consisting of Initial Data, Conversion, Normalization, Normalization Weighting, Positive and Negative Ideal Solutions, Separation Measure, Final Result) and Log out.

\section{c. Admin Home Interface}

The admin homepage interface displays the main page after the user or system user logs in, and is presented in Figure 48. The overall program code (index.php) of this interface is presented in the appendix.

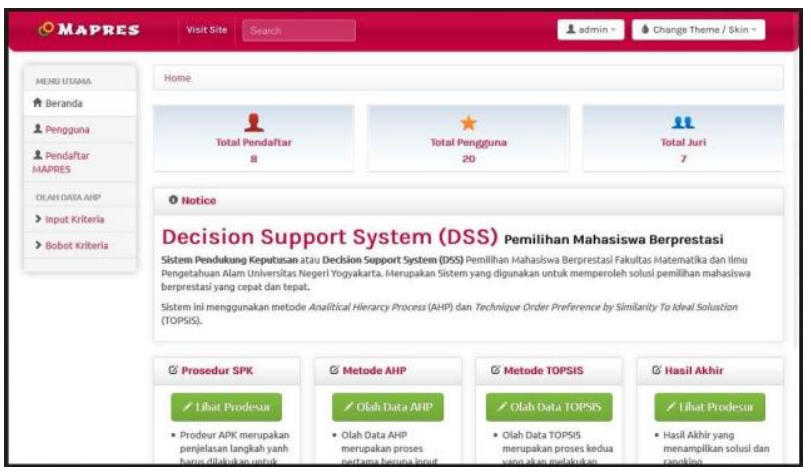

Figure 4. Admin Home Interface

\section{d. User Interface}

The user interface displays user/user information registered in the decision support system for selecting outstanding students. The program code (user_list.php) as a whole from the interface is presented in the appendix. There is a user table that shows user/user information in the decision support system for selecting outstanding students. The added user menu is useful for adding users to the system. Figure 49 is an image of the User menu interface. 


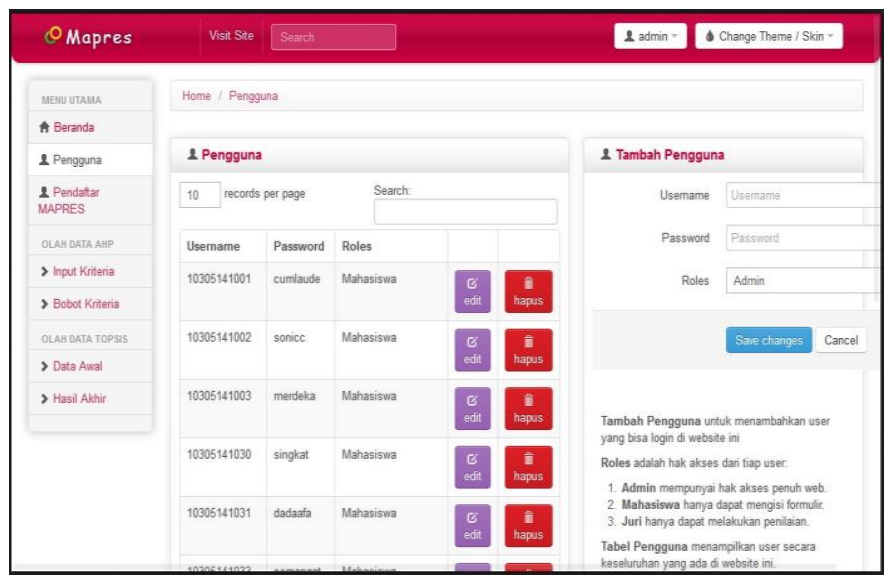

\section{e. Mapres Registration Interface}

Figure 5. User Interface

The following image is the MAPRES registrar's interface displaying information on data from the selection participants for the selection of outstanding students. The program code (view_pendaftar.php) as a whole from the interface is presented in the appendix.

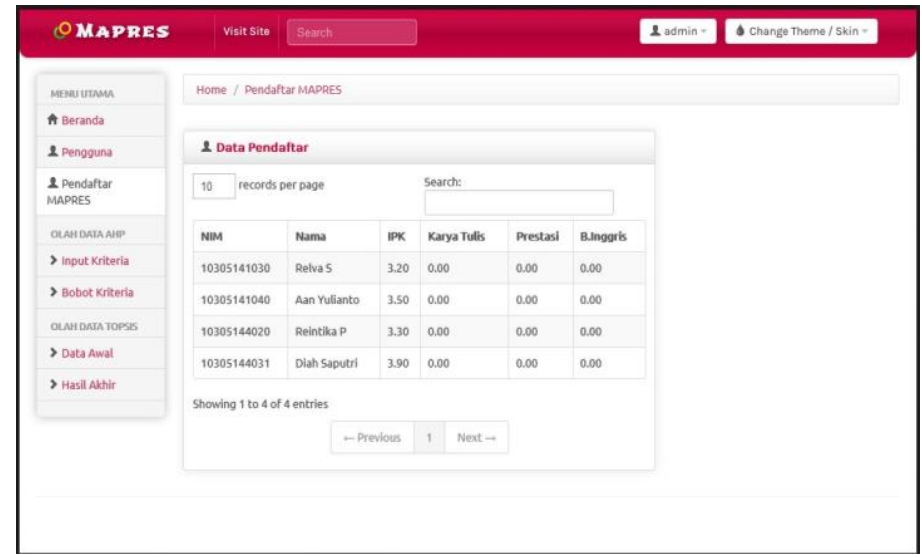

Figure 6. Mapres Registration Interface

\section{f. Criteria Input Interface}

The input criteria interface displays information in the form of an input table in the form of the weighting of each selection criteria for outstanding students which is presented in Figure 51. Admin can choose the value according to the value provided. The weighting of the criteria is done by comparing each criterion. The program code (input_kriteria.php) as a whole from this interface is presented in the appendix.

Example: Writing with GPA is more important than writing, so it is given a weight of 5, while the opposing weighting, namely GPA with written work, is left blank, because later it will be processed by the system so that the weight becomes $1 / 5$. 


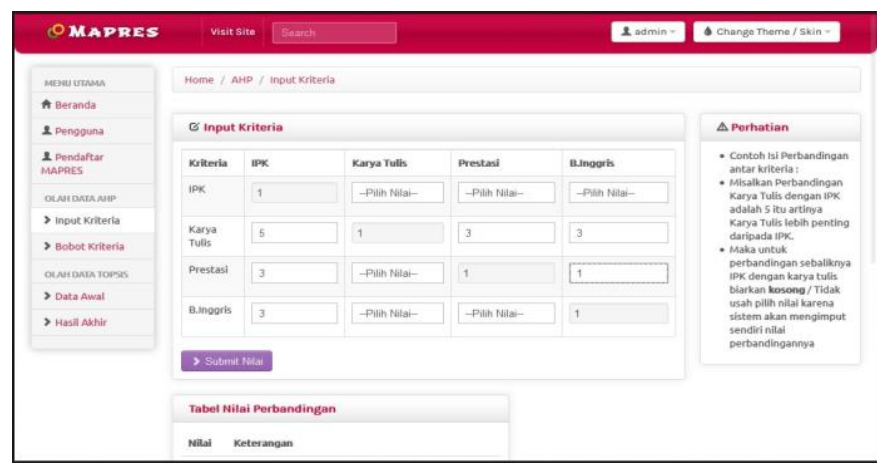

Figure 7. Criteria Input Interface

\section{g. Normalization Interface}

The normalization interface displays information on the normalization results from the criteria table and is presented in Figure 6.

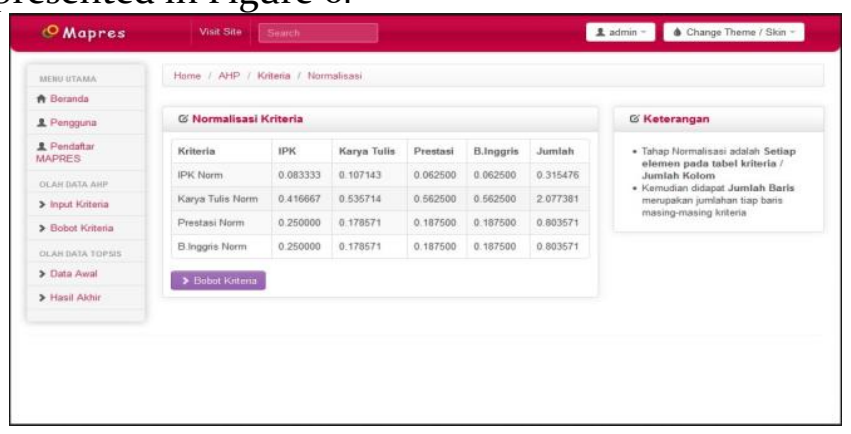

Figure 8. Criteria Normalization Interface

$$
\begin{aligned}
\text { Nilai elemen baru } & =\frac{\text { Nilai setiap elemen matrik } A}{\text { jumlah kolom lama }} \\
a_{i j} \text { baru } & =\frac{a_{i j}}{\text { jumlah kolom lama }} \\
a_{11} \text { baru }=\frac{a_{11}}{12} & \\
a_{11} \text { baru } & =\frac{1}{12}=0,083333
\end{aligned}
$$

\section{h. Criteria Weight Interface}

The criteria weight interface displays information on the priority weighting results for each criterion and information about the weighting of these criteria whether they are consistent (true) or inconsistent (false) through consistency calculations, which are presented in detail on the Consistency Calculation Details button which is presented in Figure 54. Program code (criteria_weighting. php) and (process_weight.php) as a whole of this interface is presented in the appendix. 


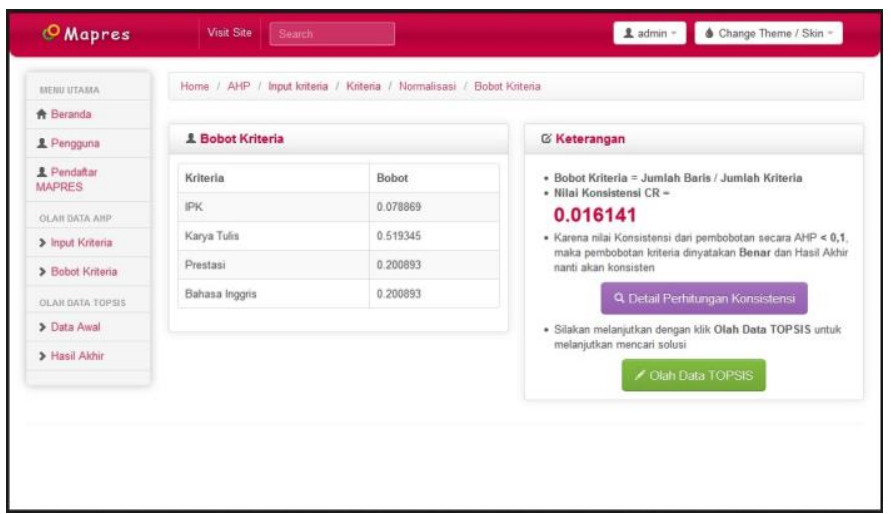

Figure 9. Criteria Weight Interface

An example of finding one of the priority weights on the criteria is done by:

$$
\text { bobot kriteria IPK }=\frac{\text { jumlah baris }}{\text { jumlah kriteria }}
$$

bobot kriteria IPK $=\frac{0,315476}{4}=0,078869$

\section{i. Consistency Interface}

The consistency interface in Figure 8 displays detailed information on the consistency test/Consistency Ratio (CR) from the criteria priority weight table. The overall program code (consistency.php) of this interface is presented in the appendix

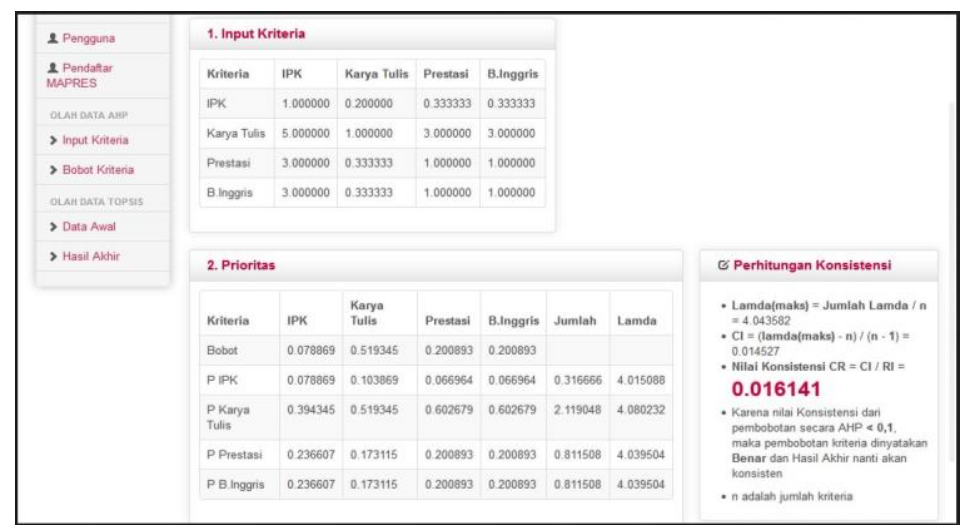

Figure 10. Consistency Interface

\section{j. TOPSIS Data Processing Interface}

TOPSIS data processing consists of initial data interface, conversion, normalization, normalization weighting, positive and negative ideal solutions, separation measures and final results. The following is an explanation of each of these interfaces:

\section{k. Initial Data Interface}

The initial data interface in Figure 56 displays registrant data information in the form of a table by displaying the value of each criterion (GPA, paper, achievement and English). The program code (data_awal.php) as a whole of this interface is presented in the appendix. 


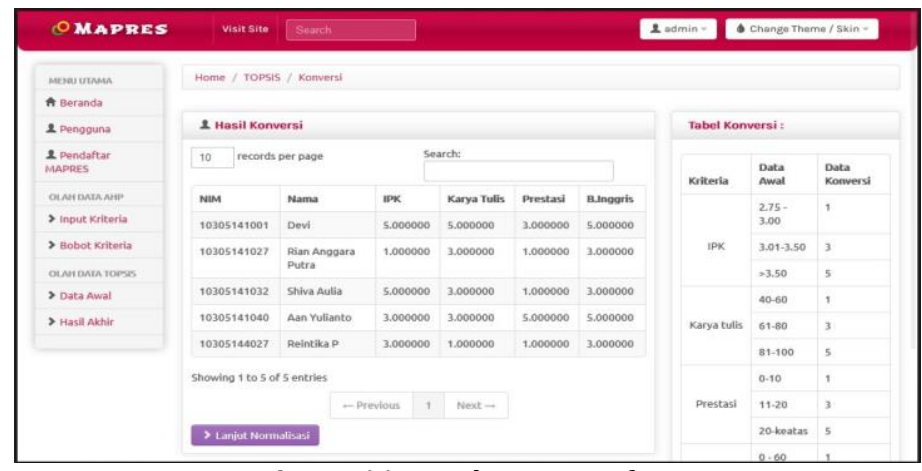

Figure 11.Initial Data Interface

\section{Conversion Interface}

The conversion interface in the following figure displays information on the value of the conversion results from each registrant according to the conversion table that has been prepared determined. The program code and (roses_konversi.php) as a whole of this interface are presented in the appendix.

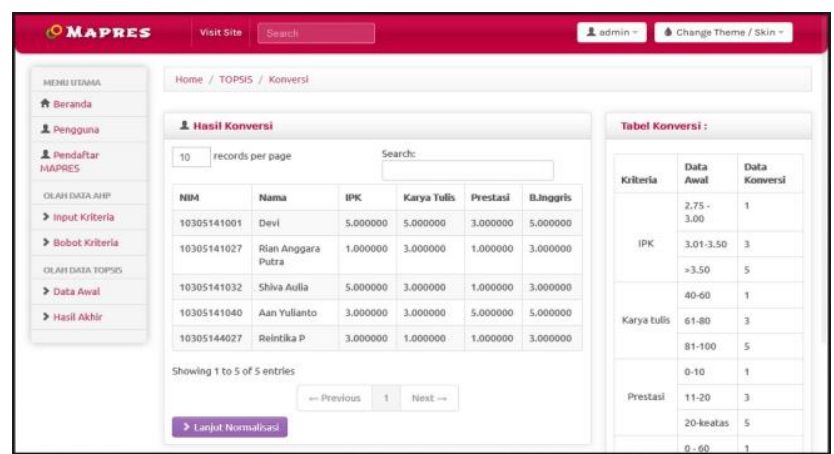

Figure 12. Conversion Interface

The conversion process is carried out based on the priority weight of the priority criteria by converting the initial data into numerical values according to Table 1 below;

Table 1 Data Criteria

\begin{tabular}{ccc}
\hline Criteria & Preliminary data & Conversion Data \\
\hline \multirow{3}{*}{ GPA } & $2.75-3.00$ & 1 \\
& $3.01-3.50$ & 3 \\
Papers & $3.51-4,00$ & 5 \\
& $40.00-60.00$ & 1 \\
& $61.00-80.00$ & 3 \\
Achievement & $80.01-100$ & 5 \\
& $<10$ & 1 \\
English & $10-19$ & 3 \\
& $>20$ & 5 \\
& $<60.00$ & 1 \\
& $60.00-80.00$ & 3 \\
\hline
\end{tabular}

\section{m. Normalization Interface}

The normalization interface in the following figure displays the result information from the normalization of the previous conversion table. The program code (norm1.php) and (process_norm1.php) as a whole of this interface is presented in the appendix. 


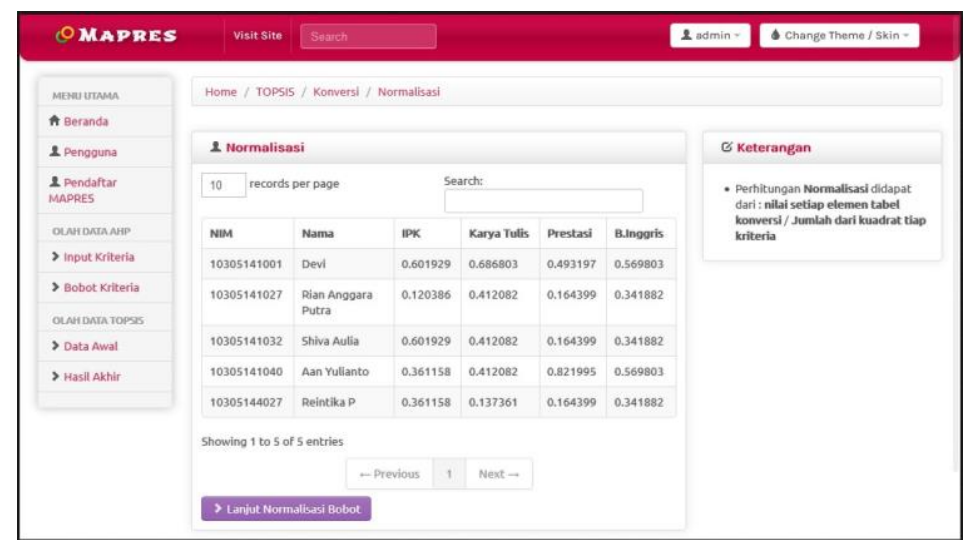

Figure 13. Normalization Interface

An example of calculating the normalization of these criteria:

$f_{11}=\frac{5}{\sqrt{5^{2}+1^{2}+5^{2}+3^{2}+3^{2}}}=0,601929265$

n. Normalized Weighting Interface

The normalization weighting interface displays information on the results of the normalization table matrix multiplication in Figure 58 with the AHP criterion weight table matrix (the following figure). The program code (norm2.php) and (process_norm2.php) as a whole of this interface is presented in the appendix.

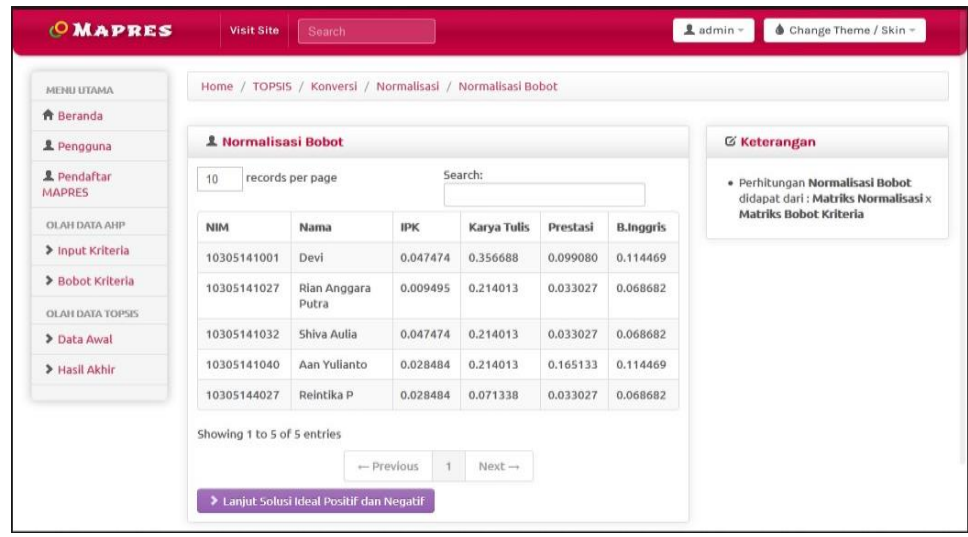

Figure 14. Normalized Weighting Interface

An example of the normalization weighting calculation is as follows: The ipk priority weight is 0.078869048

Pembobotan normalisasi $f_{11}=f_{11}$ normalisasi $x$ bobot prioritas ipk $=0,601929265 \times 0,601929265$$$
=0,047473588
$$

\section{o. Positive and Negative Ideal Solution Interface}

The interface of the positive and negative ideal solutions in the following figure displays information on the results from the normalization weighting table for which positive and negative solutions are sought 


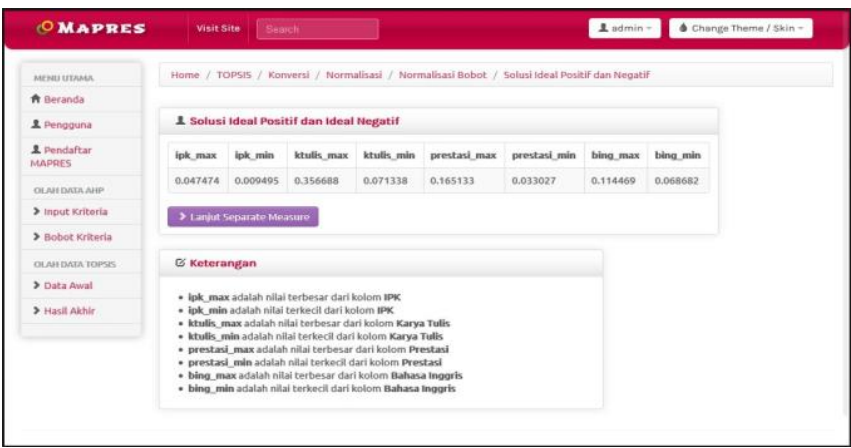

Figure 15. Positive and Negative Ideal Solution Interface

The positive ideal solution is obtained from the maximum value of each column of criteria, while the negative ideal solution is the minimum value of each column of criteria.

\section{p. Separation Measure Antarmuka Interface}

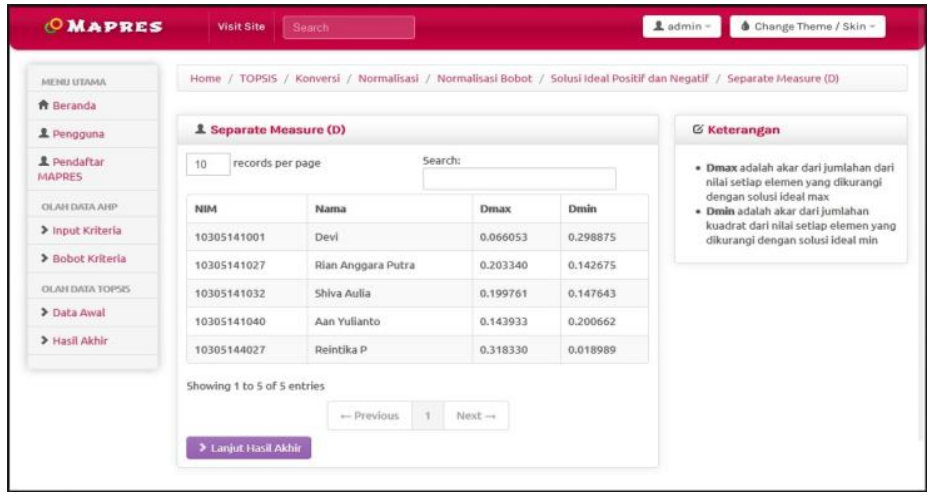

Figure 16. Separation Measure Antarmuka Interface

\section{q. Final Result Interface}

The Final Result interface displays information on the final results of the entire process and ranking so that a solution is obtained.

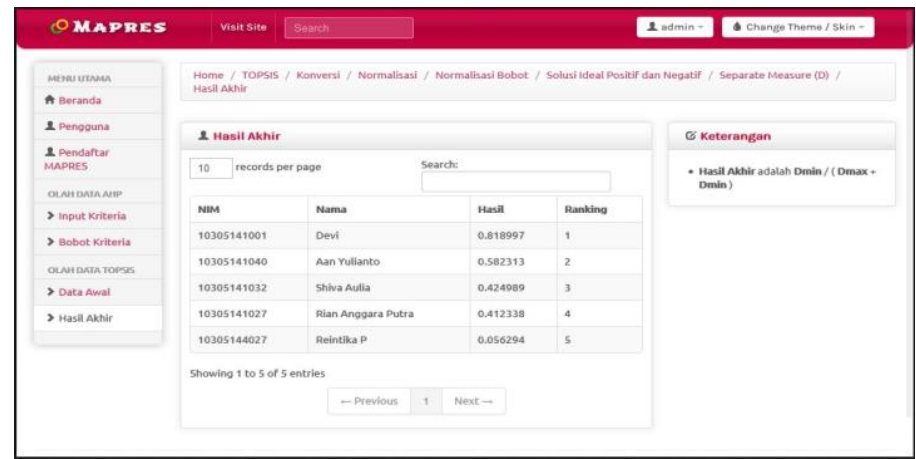

Figure 17. Final Result Interface

\section{Conclusion}

Based on the results of the discussion of the Decision Support System for the Selection of Outstanding Students, it can be concluded as follows: 
SPK is built based on a website designed using Sublime software (text editor), Database Management System (DBMS) MySQL Xampp 7 and the PHP programming language. SPK consists of 4 users

namely: a.) Administrator is the Student Affairs Staff or Chair of the Selection Committee for outstanding students who has the authority to enter the weight of the assessment criteria using the AHP method and data processing using the TOPSIS method. Administrators can add and remove existing users. b). The jury is a lecturer who has limited authority to enter. input value to student data. The jury consists of a written jury, an achievement jury and an English jury. c). Student is a participant in the selection of outstanding students at FMIPA who has limited authority to enter data input in the form of filling in the registration and achievement forms. d). Faculty leaders are the Dean, Deputy Dean, and Head of the Department whose authority is limited to seeing the results of announcements of outstanding students.

The designed SPK has 3 main functions, namely registration, judging, and data processing of outstanding student candidates so that it can be used as an alternative tool for decision-making solutions for outstanding students.

The AHP method is used for the process of weighting the criteria according to the request (input) and the TOPSIS method can be used for processing student data so that the winning student solution is obtained.

Based on the Betha test, the results showed that Correctness was included in very good criteria, Reliability was included in very good criteria, Integrity was included in very good criteria, Usability was included in good criteria, meaning that SPK can meet user needs, such as assisting the registration process, judging and processing participant data. selection of outstanding students. SPK can display information according to user input correctly. Instructions for using the system help the user. SPK is safe from unauthorized parties. SPK display is attractive and easy to use..

\section{Reference}

Fishburn, P., C., 1967, Additive Utilities with Incomplete Product Set :Application to Priorities and Assigments, Operations Research Society of America (ORSA), Baltimor, MD, U.S.A.

Haedar, T., 1997. Prinsip-prinsip Networking Planning. PT. Gramedia. Jakarta.

Holloway, C.A, 1979. Decision Making Under Uncertainty: Models and Choice.Prentice-Hall, New Jersey.

Kusrini, 2006. Konsep dan Aplikasi Sistem Pendukung Keputusan. Penerbit Andi.

Kusumadewi, S.etal.2006. Fuzzy Multi-Attribute Decision Making (FUZZY MADM). Graha Ilmu.Yogyakarta.

MacCrimmon, K. R., 1968, Decisionmaking among Multiple Attribute Alternatives. A Survey and Consolidated Approach, RM-4823-ARPA, the Rand Corporation, Santa Monica (CAL).

Mulyono, S., 1996. Teori Pengambilan Keputusan. Penerbit Fakultas Ekonomi Universitas Indonesia. Jakarta.

Moore, J. H. and M. G. Chang (1980). "Design of Decision Support Systems", Data Base 12(12).

Paramita, Dyah Ayu, 2013. Efektifitas penggunaan metode SAW (Simple Additive Weighting) dalam sistem pendukung keputusan penentuan pemberian kredit peminjaman uang tunai PT. BPR X. Perpustakaan Universitas Sanata Dharma.Yogyakarta.

Sprague, R. H. and Watson H. J., 1993. Decision Support Systems: Putting Theory Into Practice. Englewood Clifts, N. J., Prentice Hall

Suryadi, Kadarsah,2002, Sistem Pendukung Keputusan, Remaja Rosdakarya, Bandung.

Taha, H.A., 1982. Operations Research: an Introduction. New York: Macmillian.

Turban, Efraim., (1995). Decision Support and Expert System: Management Support System. Forth Edition. Prentice Hall International Inc. New Jersey.

Turban, Efraim dan Jaye Aronson. 1998. Decision Support Systems and Intelligent Systems. Fifth Edit ion. Prent ice-Hall, Inc.

Turban , Efraim \& Aronson, Jay E. 2001. Decision Support Systems and Intelligent Systems. 6th edition. Prentice Hall: Upper Saddle River, NJ. 